\title{
Decolonization and the spectre of the nation-state
}

\section{Peo Hansen (1)}

Institute for Research on Migration, Ethnicity and Society, Linköping University, Norrkoping, Sweden

\section{Correspondence}

Peo Hansen, Institute for Research on Migration, Ethnicity and Society, Linköping University, REMESO SE-601 74 Norrköping Sweden.

Email: peo.hansen@liu.se

\section{Funding information}

Riksbankens Jubileumsfond for the Advancement of the Humanities and Social Sciences., Grant/Award Number: P18-05951

Gurminder Bhambra's Annual British Journal of Sociology Lecture ends with a call 'for a better social science'. Such a science would be 'located in a more adequate understanding of the shared histories that have configured our present, to find more expansive and generous solutions to the problems that face us.' (Bhambra, 2021, p. 15) Bhambra practices what she preaches. Argued with remarkable clarity, her talk delivers both compelling theoretical claims and much corroborating empirical evidence. As such, the talk is highly original and leaves no doubt as to the great amount of work and meticulous historical research that have gone into it.

But Bhambra's intervention does so much more than live up to its call for a better social science. Upon a careful reading, I will argue, the implication of her arguments should rather be seen as nothing less than a call for a paradigm shift in how the social sciences approach the nation-state, both historically and in our own times. That is to say, perceiving of Britain historically as a nation-state or as an imperial state will make all the difference; and, as Bhambra argues, it is precisely the failure to grasp the imperial fact that prevents us from grasping 'the shared histories that have configured our present'.

Below I will reflect on the crucial imperial fact outlined by Bhambra and apply its radical consequences for our approach to the broader Western European scene and the world at large in the postwar period. If Britain was not a nation-state, neither were most Western European states. Belgium, Denmark, France, the Netherlands, Portugal and Spain all held colonial possessions in the postwar period. Italy was eager to regain its colonial foothold in Africa and was given the trusteeship of Somaliland (its former colony) by the UN in 1950, and it also sought the trusteeship over Libya's Tipolitania region. This is enough to shed light on the fact that the world in the postwar period was not national but rather imperial or colonial. Adding the ambitions of the two superpowers clarify the picture further. Hence, there was no general nation-state system in place, and the creation of the United Nations in 1945 had little intention of changing that fact. As Mazower (2009, p. 23) has shown, '[t]he UN's later embrace of anti-colonialism has tended to obscure the awkward fact that like the League [of Nations] it was a product of

This is an open access article under the terms of the Creative Commons Attribution-NonCommercial License, which permits use, distribution and reproduction in any medium, provided the original work is properly cited and is not used for commercial purposes.

(c) 2021 The Authors. The British Journal of Sociology published by John Wiley \& Sons Ltd on behalf of London School of Economics and Political Science 
empire and indeed, at least at the outset, regarded by those with colonies to keep as a more than adequate mechanism for its defence'.

What I will argue, then, is that our contemporary nation-state system is not the invention of Westphalia and European objectives, but rather the product of decolonization and thus a reaction and alternative to the European designs for the modern world order, in general, and the postwar order, in particular. Delhi in 1947, Dien Bien Phu in 1954, Accra in 1957 or Algiers in 1962 are, thus, more accurate symbols of the birth of the nation state system than our current fictions around the Peace of Westphalia in 1648. Asians and Africans pioneered the nation-state system that most people-formally speaking-live in today. And since the Europeans opposed such a system, its implementation was often a very bloody affair, as seen in the numerous wars and crimes against humanity that colonial powers waged in the postwar period-all for the purpose of preventing the advent of the nation-state system and preserving the colonial system.

In relation to this, I will also argue that Bhambra's work helps establish a historically informed critique of methodological nationalism, as opposed to the many misconceptions perpetuated by our current theoretical consensus of what 'methodological nationalism' entails.

Bhambra opens her talk with the following statement:

The consolidation of the British welfare state in the mid-twentieth century did not only coincide with the systematic dismantling of the British empire but was significantly shaped by it. However, the dominant narratives situate it firmly within a national context. This is as true of academic scholarship as it is of popular representations. For example, one need only think of Ken Loach's The Spirit of $45 .^{1}$

Ken Loach's celebrated documentary about the sweeping social reforms ushered in by the Labour government in 1945 is a very good example indeed. As put by one voice in the film's official trailer: 'The older generation has got an absolute duty to come forward and join with young people and start talking about what was the vision in 1945.' But the Labour government that is remembered for its social reforms is the same Labour government that in 1945 was determined to consolidate the British empire. As the foreign secretary Ernest Bevin declared in the House of Commons in February 1946:

When I say I am not prepared to sacrifice the British Empire what do I mean? I know that if the British Empire fell, the greatest collection of free nations would go into the limbo of the past, or it would be a disaster. I know, further, it would mean that the standard of life of our constituents would fall considerably.

(quoted in Saville, 1993, p. 4)

The spirit and vision of 1945 was imperial; and as Bhambra shows, the building of the postwar welfare state on the British islands was partly premised on the continuation of colonial exploitation around the world. By the same token, the narrative about the national and social spirit of 45 is premised on being kept dissociated from the imperial spirit of 45 .

There are countless similar examples of such necessary dissociations. Let me just point to a couple more, one from the French and the other from the EU context. Take the well-known images of the masses of people in Paris on 8 May 1945 (Victory in Europe Day), flocking the streets to celebrate the defeat of Nazi-Germany. For this VE day narrative to remain joyous and rosy, however, it needs be left divorced from the fact that 8 May 1945 also was 
the day when the massacres in the Algerian cities of Gulam, Kherrata and Sétif began. Algerian pro-independence demonstrations on 8 May unleashed a wave of mass slaughter by the French army that left thousands dead. Hence, the spirit of liberation from the Nazi tyranny walked hand in hand with a determined and tyrannical effort of colonial reinforcement.

Five years later, almost to the day, on 9 May 1950, French foreign minister Robert Schuman presented what was to become known as the Schuman Declaration, or Schuman Plan, announcing the Franco-German initiative to jointly regulate extraction and production of coal and steel. The Schuman Plan gave birth to the European Coal and Steel Community (ECSC) and subsequently to the European Economic Community (EEC) in 1957-today's European Union. Since 1985 the EU officially celebrates 9 May as 'Europe Day': 'on 9 May 1950, the foundation of the European Union as we know it was set out in an extraordinary declaration based on two core principles: peace and solidarity.' (European Council, 2020) But when Robert Schuman pleaded for 'World peace', which are the very first words of his Declaration, Schuman was also busy overseeing an extremely brutal colonial war in Indochina, killing as many as half a million Vietnamese. This is what needs to be erased for the EU to celebrate the spirit of the Schuman Declaration as a plea for 'World Peace'.

The Schuman Declaration is interesting also for what it explicitly includes. As stated in the two-page declaration: 'With increased resources Europe will be able to pursue the achievement of one of its essential tasks, namely, the development of the African continent.' (European Union, n.d.) Most likely the Declaration's Africa passage was prompted by René Mayer, then Minister of Justice, and Jean Monnet, both of them keen on having the African colonies incorporated into the European project. According to them, France could give Africa as a 'dowry to Europe' and as a way to 'seduce the Germans' (McKay, 1963, p. 139; Monnet, 1978, p. 300; Uri, 1991, p. 80).

In 1950, it was still unquestionably natural for European statesmen to deny sub-Saharan Africa any political agency whatsoever. Whether or not 'Africa' was an inherent part of the European project was not for the Africans to decide. The same approach applied to the individual states that colonized Africa. African independence was not on the agenda. From the British perspective, Africa was the place where 'a permanent line of British defence could and should be decisively drawn', the place 'where the British Empire might be maintained indefinitely' (Louis, 1984, pp. 108-109). This stood in sharp contrast to how Western Europe perceived of their empires in Asia, the Middle East and, to some extent, North Africa. Strong anti-colonial sentiments and independence movements had been brewing here since well before the war had ended with Japan's capitulation in August 1945. Numerous such movements had formed already in the wake of World War I and its 'Wilsonian moment' (Manela, 2007), which, at first, had seemed to elevate national self-determination to a universal principle and thus produced the impression 'that a window of opportunity had opened and thrust the issue of colonial liberation to the fore' (Manela, 2007, p. 220). Although this turned out to be a deceptive impression, it served to galvanize and radicalize anti-colonial movements vowing not to let the moment slip a second time once the window reopened in 1945.

Knowing full well what was in the offing, however, colonial powers were not ready to give in, but where equally engaged in preparing for the opposite development of stemming the tide of independence movements in Asia and the Middle East-and also in North Africa, as the massacres that began on VE day in Algeria make clear. Britain's initial imperial actions in 1945 and 1946 actually effectuated a significant expansion of European imperialism in Asia. Through military interventions in French Indochina (Vietnam) and the Dutch East Indies (Indonesia) in 1945, Britain helped pave the way for France's and the Netherlands' restoration of the colonial control that had been lost during the war (Bayly \& Harper, 2007). The British decision rested with the firm belief that the rebuilding of the French and Dutch empires in Asia would be imperative for Britain's ability to hold on to its own Asian possessions. As Bhambra (2021, p. 13) points to in her talk, the lifeline of dollar earnings coming from Malaya's rubber and 
tin production, for one, could simply not be lost at this critical hour (see e.g., Lawrence, 2007). 'The frontiers of Malaya', said Britain's ambassador to Thailand, 'are on the Mekong' (quoted in Lawrence, 2007, p. 122).

But as the 1950s wore on European powers soon lost the great majority of their colonial possessions in Asia and the Middle East. Europe's declining influence walked hand in hand with Asia's rapid transformation into a major theatre of the early Cold War, climaxing with the communist victory in China in 1949 and the Korean War shortly thereafter. At the same time, developments in the Middle East and Iran were moving in a similar direction, with colonial and Cold War struggles often inextricably intertwined. Given Africa's (with the crucial exception of Egypt and, to some degree, North Africa in general) relative distance from this nexus of Cold War and anti-colonial struggles, many Europeans thus believed that a reinforcement of Europe's African possessions would serve to prevent the push for decolonization in Asia from gaining a foothold on the African continent. In so doing, this would also keep the superpowers at arm's length from African affairs, thereby preventing the Cold War logic from infiltrating Africa.

Both Britain and France advocated such a development. Britain's strong-minded commitment to the revival of African colonialism was owed chiefly to the belief in the continent's magnificent economic potential. As such, and as emphasized by Bhambra (2021, p. 13), it presented Britain with a priceless opportunity to resolve its appalling financial situation, its overall economic decline and, not least, its embarrassing dependence on the U.S. (see also Butler, 2002, pp. 81-85). This manifested in Britain's unparalleled investment in its African colonies in the early postwar years; and as Britain's economic situation showed further signs of structural weakness after 1947, this precipitated, as Butler (2002, p. 82) puts it, 'a brief, but unprecedented fixation with drawing on colonial resources'. As the Chancellor of Exchequer, Stafford Cripps, spelled out before the African Governor's Conference in November 1947:

The economies of Western Europe and Tropical Africa are so closely interlocked in mutual trade, in the supply of capital and in currency systems that their problems of overseas balance are essentially one. Tropical Africa is already contributing much, both in physical supplies of food and raw materials and in quite substantial net earnings of dollars from the sterling area pool. The further development of African resources is of the same crucial importance to the rehabilitation and strengthening of Western Europe as the restoration of European productive power is to the future progress and prosperity of Africa. Each needs and is needed by the other. In Africa indeed is to be found a great potential for new strength and vigour in the Western European economy and the stronger that economy becomes the better of course Africa will fare.

(quoted in Kent, 1989, pp. 58-59)

Under the headline 'Cripps says colonies hold key to survival', The New York Times (1947a) underscored that Cripps' contention had 'been widely accepted by the country's top economists and business men'.

'Despite drastic changes in her position abroad', The New York Times (1947b) wrote in October 1947, 'Great Britain remains a powerful imperial nation.' To be sure, the report went on, India was lost, Palestine on its way and, while still strong, its ties to the Middle East and the Far East were certainly also showing signs of strain. In contrast to this development however, the Times could also confirm that 'Britain's interests in Africa-from Kenya, the Sudan and Nigeria right down to the Cape-are expanding.' Indeed, in 1947 Africa was taking the place of India 'as one of the ultimate justifications of the British Empire'. As Louis (1984, p. 109) puts it, much of it echoed the spirit of the late nineteenth century's scramble for Africa: '[T]he map of tropical Africa would be painted a new shade of British red from Mombasa to Lagos, with the vital centre in the Sudan. In the Sudan rail or air links could be provided, if the Egyptians were amenable, to Cairo and Cape Town.' In addition, Kenya (and possibly Tanganyika too) was seen by prime minister Clement Attlee, as he suggested in 1946, as the primary candidate for hosting a new main base for the protection of Britain's imperial interests, serving first as a backup to Egypt and ultimately as its replacement (Bullock, 1983, p. 243; The New York Times, 1946). 
Africa's splendid economic prospects notwithstanding, Britain's initial enthusiasm could not rest with this alone. The presumed viability of the enterprise was also intimately bound up with an equally presumed temporal buffer. As already noted, then, Britain felt it could work under the assumption that its African plans had time on their side, given that the nationalist and communist currents materializing elsewhere in the Empire still were seen to be at a safe distance from tropical Africa. 'With regard to the African and his aspirations', it was asserted in International Affairs in 1948, 'rapid political evolution is not of much concern to him; nor is it his primary need.' Rather, what the African was said to be seeking, and what Britain should provide for, was 'nourishment for his body and his mind' (Kraft, 1948, p. 225). 'Africa', to use Gallagher's (1982, p. 146) depiction, 'would be the surrogate for India, more docile, more malleable, more pious.'

This is crucial, because the same temporal calculus was embraced by France and by many of those pushing for European integration in the 1940s and 50s. And whereas Britain's African enterprise would run out of steam as the 1950 s wore on, France and what became the EEC would press on with the plans to tie the African colonies closely to the European enterprise. This plan went under the name Eurafrica and was successfully concluded with the EEC's decision, in the 1957 Rome Treaty, to absorb or associate France's and Belgium's African colonies. In fact, the African colonies and their enormous natural resources figured prominently on the agendas of practically all the postwar organizations and institutions of European integration (see further Hansen \& Jonsson, 2014).

At the European Movement's grand Congress of Europe in The Hague in May 1948, for instance, it was agreed that ' $t$ t]he European Union must, of course, include in its orbit the extensions, dependencies and associated territories of the European Powers in Africa and elsewhere, and must preserve the existing constitutional ties which unite them.' (quoted in Hick, 1991a, pp. 335-336). One of the key actors at the Congress, the European Union of Federalists (EUF), maintained that 'Europe as an entity will be viable only if the links which unite it with countries and dependent territories scattered all over the globe are taken into account.' The EUF was also adamant that the Council of Europe, which was founded in 1949, should take a leading role in the development of the colonies in Africa, arguing that ' $[t]$ he era of national ownership of colonial territories is past. [...] From now onwards a common European policy of development for certain regions of Africa should be taken in hand, for the benefit of all the peoples concerned.' (quoted in Hick, 1991b, pp. 84-90)

Bhambra brings up the crucial importance of colonial exports for Britain's much needed dollar earnings after the Second World War. The dollar deficit was a huge and chronic problem shared by all Western European states in the postwar period, and organizations such as the Organisation for European Economic Co-operation (OEEC) OECD) and the Council of Europe invested a lot of energy in trying to resolve it. The answer? Africa! Immediately after its establishment in 1948, the OEEC decided to form an Overseas Territories Working Group in order to promote European cooperation in colonial affairs, particularly in Africa. In its extensive report from 1951, focusing on investments in the colonial territories south of the Sahara, the OEEC (1951, p. 20) stated that '[i]t is in the interest of the whole free world that the [colonial] territories, which form part of it, should endeavour to speed up and increase the production of scarce materials.' Important too is that the report was completely void of indications that colonialism in Africa might someday come to an end; on the contrary planning for the African colonies was unreservedly described as 'a long-term task' in an African terrain characterized by 'political security' (OEEC, 1951, p. 72).

The Council of Europe's Strasbourg Plan also called for Western Europe's joint large-scale investments in the exploitation of the African colonies' vast yet largely untapped natural resources. In so doing Western Europe would be able to reduce its dependence on dollar imports of raw materials, which, in turn, would facilitate Western Europe's transition into 'a third economic group standing midway between the Communist and the dollar areas' (Council of Europe, 1952, p. 15). As explained by the French representative Raphaël Saller during the Council of Europe's Consultative Assembly debate on the Strasbourg Plan: '[N]o European Political Community can survive without the support and co-operation of overseas countries having constitutional links with Europe. This is an ever-present economic reality which Europe must perforce recognize if 
she is not to be doomed to perish.' (Council of Europe, 1952, p. 16) Meanwhile, the UK representative Lord Layton argued that 'it is clear that we have to think of these overseas territories not as the possessions of any one country [...]; they have to be integrated with all the countries of Europe and all the overseas territories' (Council of Europe, 1952, p. 140). This chimed with practically all of the representatives. For instance, Denmark's Hermond Lannung emphasized 'the overriding importance of greater co-operation and of a major joint European effort in Africa if we do not wish to see Africa lost to European influence, culture, trade, etc. and, in the long run, for that influence to be replaced by that of another continent.' Europe had just lost the 'battle of Asia', Lannung asserted, and now its members needed to unite in order to not also lose 'the battle of Africa'. 'Here we have before us a great concrete and practical task which calls for the utmost collaboration of us all.' (Council of Europe, 1952, p. 154)

This outlook also permeated and enabled the EEC's colonial association regime that was agreed in the Rome Treaty in 1957. During the treaty negotiations, colonial matters were assigned to a special intergovernmental AdHoc Overseas Territories Group. In December 1956 it presented a report that outlined the benefits of associating the French and Belgian African colonies:

Economically speaking, the European member states of the common market have an essential need for the cooperation and support that the overseas territories-particularly the African ones-are able to offer in order to establish long-term balance of the European economy. The sources of raw material, variegated and abundant, which the overseas territories dispose of are likely to ensure for the entirety of the European economy of the common market the indispensable foundation for an expanding economy and present the additional advantage of being situated in countries whose orientation may be influenced by the European countries themselves. In addition to the mineral riches of all kinds and the agricultural and exotic products of the overseas countries, it is fair to mention as a concrete incentive, the results of very recent prospections in the petroliferous area carried out in connection with the systematic inventorying of the immense African reserves of metals, phosphates, hydraulic energy, etc. ${ }^{2}$

In a later section, the report compared this project to the Marshall Plan for Europe, insisting that the association of the overseas territories should be undertaken in a similar spirit. The report concluded as follows:

The proposed enterprise entails consequences of major importance for the future of Europe. [...] In aiding Africa and supporting itself on her, the community of the six is able to furnish Europe with its equilibrium and a new youth. It is with this perspective that all other elements of information assembled in the present report should be understood. ${ }^{2}$

This brief and impressionistic overview of Western Europe's approach to colonialism up until the late 1950s serves to clarify why Bhambra's argument has general bearing, well-beyond the British context. That is to say, her approach needs to be adopted for all of Western Europe (and beyond), including those states in Western Europe that did not possess colonies or played a very minor role in postwar colonial relations.

As shown above, the various organizations for Western European unity, cooperation and integration are crucial to consider here since these included states without colonies but which, nevertheless, could be very eager to preserve and reap the benefits of colonialism by means of European cooperative frameworks. Take the case of West Germany. True, postwar West Germany did not have any colonies and was no empire. Yet, its governments under Chancellor Konrad Adenauer were warm friends of European colonialism and wanted to use the EEC to 
strengthen and develop it for the benefit of West Germany and to bolster Europe's geopolitical and cultural stamina vis-à-vis both the Soviet and the Anglo-American blocs. A diehard champion of the Franco-British Suez campaign against Egypt in 1956, equating-as so many European statesmen did-Nasser with Hitler, Adenauer contended that Western Europeans, and especially the French and the Germans, had to stick together in support of the invasion (Schwartz, 1997, pp. 240-245). Suez, for Adenauer, thus proved his point of a united 'third force' Europe as the only antidote to what he saw as the US and Soviet policy of carving up the world between them (Granieri, 2003; Schwartz, 1997, p. 243). Adenauer also justified his moral support for France's intervention in Egypt with reference to France's unconditional right to keep Algeria and to protect it soldiers against rebels who, according to Paris, were supported by Nasser. 'Algeria', Adenauer asserted in November 1956, 'is not a French colony, but a province of France since 1830 with 1.5 million white French men and women.' (Schwartz, 1997, p. 190)

Not only did Adenauer believe in the 'superiority of Western civilization'; he was equally convinced of the inherent racial inferiority of Africans, and it was therefore inconceivable, as he phrased it, "that Africa, as a black continent, could be independent alongside the other continents"' (quoted in Schwartz, 1997, p. 191) As Schwartz (1997, p. 238) notes, 'Adenauer spoke of the "appearance of non-white peoples on the political stage of world events"' and found it deeply disturbing since he thought it could have detrimental effects on the future constitution of the UN (Schwartz, 1997, pp. 254-255). Indeed, when U.S. president Eisenhower visited Achmad Sukarno's Indonesia-one of the Bandung movement's most prominent leaders-in May 1956, this 'sent shivers through Bonn'. Not only had Eisenhower's visit been friendly, but the president had also publicly accepted the non-alignment, or neutrality, of some of the newly independent countries-something that was anathema to Adenauer (Brady, 2010, p. 175). Adenauer's hostility towards the liquidation of colonialism would not let up. In early 1960 Adenauer informed his cabinet that he had received a note from de Gaulle during their most recent consultations that recounted the expected new members of the UN. Adenauer, Schwartz (1997, pp. 254-255) writes, 'read out: "Thirty black states, twenty Islamic states, eighteen Asian, non-Muslim nations, twelve Soviet states, eighteen Central and South American countries-ninety-eight in all." Compared with fifteen Western states. "These are the prospects for future world policies."'

1960 marked the end of colonialism in large parts of Africa. This was a surprise that European leaders just 2 to 3 years prior had not been able to anticipate. And Adenauer was certainly one of them. On 15 February 1957 Adenauer explained the great advantages of the EEC's colonial association regime to his cabinet. 'The Chancellor', the cabinet protocols relate, 'is of the opinion that in the long term, France offers much better economic prospects than Britain. France possesses a latent wealth, just think of the Sahara with its oil and uranium deposits. Equatorial Africa also constitutes a significant reserve. In comparison, Britain's development points to a substantial decline.' (Kabinettsprotokolle der Bundesregierung, 1957/2000, p. 144). Yet, only three years later the world had changed beyond all recognition. In June 1960, an article in the German daily Die Welt carried the anxious headline 'Läuft Afrika der EWG davon?' (Is Africa running away from the EEC?). The article asserted that the time when the Treaty of Rome was drafted, 'the fact that Europe would be faced by independent states in Africa within only a few years could scarcely have been anticipated'. Such independence, the author warned, risked upsetting the EEC's entire edifice of African association. Lest a new EEC strategy towards Africa was promptly launched, the article concluded, the situation could soon prove 'dangerous for Europe and hence for the West in its entirety' (Himpele, 1960).

Die Welt was certainly right in its judgement that the Treaty of Rome was negotiated under the assumption that colonialism in Africa would continue for the foreseeable future. As put by Columbia economist and UN and US government consultant in 1961, Emile Benoit, 'the assumption of the Rome Treaty that the overseas associated areas were chiefly to comprise dependent territories is no longer valid.' To this he added: 
The Community is aware that the rapid pace of change in Africa is undermining some of the assumptions upon which its original program for association between the EEC and the African countries was based. It is also aware of the enormity of the stakes involved, and it is striving to reconstruct its program in line with emerging requirements. [...] If it succeeds, its historic role will far transcend its accomplishments in Europe alone.

(Benoit, 1961, pp. 58-59)

In 1962, the Secretary of the Council of Europe's Economic Committee, Kitzinger (1962, p. 98), commented on the Rome Treaty's colonial association provisions, saying: 'They were based on a largely static conception of the political relations between the African countries and the metropolitan Member States. In the past three years that relationship has evolved beyond all expectations.' Writing a few years later, Carol Ann Cosgrove (1969, p. 77) also stressed this crucial point: 'The treaty was drafted at a time when rapid decolonization was discounted by the European metropoles, with the result that no reference was made to the possible attainment of sovereign independence by the associate except in the case of Somaliland.'

The dismal outlook on the EEC-Africa relations expressed by Die Welt in 1960 thus starkly contrasted with the Eurafrican and colonial buoyancy at the time for the Treaty of Rome's signing only three years prior. Indeed, if Die Welt agonized over the prospect of 'Africa running away from the EEC' on 2 June 1960, on 26 March 1957the day after the Rome Treaty's signing ceremony-The New York Times (1957a) took note of Europe's latest move in its run-or should we say Drang-to the South: 'Germans go to Africa: Bonn mission to study ways to develop resources.' As reported, a German delegation was heading for 'France's African colonies to survey the joint development of industrial raw materials required by West Europe'. It was also related that this formed part of the EEC accord, 'signed today in Rome', and its objective to secure 'the joint financing of the economic development of France's African colonies.' A few months later another headline in The New York Times (1957b) ran as follows: 'Europe may get new oil source: Common Economic Market could mean shift from Mideast to Africa: Resources big factor'. Again, we are reminded of the self-evident stability and durability with which the EEC's ownership of Africa was perceived in 1957. Here, in the wake of the agreement on the EEC, The New York Times recounts the upbeat mood concerning the great economic prospects proffered by the new European community's joint development of Algeria and its member's 'overseas possessions'. In as little time as 5 or 6 years, the article informs, the EEC may very well, thanks to the recently discovered oil reserves in Algeria 'bring about a most important and perhaps permanent change in the European oil picture and a partial solution to a tough foreign exchange problem'. As also noted, the EEC's 'ultimate goal appears to be a self-sufficiency in oil and some other raw materials available from the overseas possessions, mostly in Africa'.

With India and Pakistan's independence in 1947 Europe's colonial empires in Asia and the Middle East started to decline, although they were still far from done. But this was not true for Africa. Here a reverse movement took place after 1945, based on a belief that Europeans could keep Africa within its power orbit by working to isolate Africa from the cold war logic and by instituting cooperative frameworks, such as the EEC, that could pool and thus synergize colonial sovereignty, investments and benefits. For Ghana's first president, Nkrumah (1962, p. 12 ), the EEC thus 'represented a new-fangled system of collective colonialism which will be stronger and more dangerous than the old evils we are striving to liquidate'. For the leaders of the EEC and many more, then, national independence in French and Belgian Africa was not on the table until the late 1950s, and for Algeria, which was an integral part of metropolitan France, it would take even longer.

Studying the political developments and debates in the years 1945-1960 concerning the future of colonialism in Africa is very instructive. What these demonstrate is that the states that founded today's European 
Union in 1957, if we just stick to them, did neither act nor speak as the nation-states that much of our current scholarship assumes. We have already got a glimpse of West Germany's thirst for 'Grossraum' in Africa. We could also look at the Netherlands staunch support of France's war in Algeria, its foreign minister, Joseph Luns, describing the Algerian leadership as 'murderous cutthroats with whom it was impossible to deal' (quoted in Wall, 1991, p. 131). At the signing ceremony for the Treaty of Rome on 25 March 1957 Luns spoke of the treaty as assuring 'the conditions of an increasing prosperity to our old continent and permits the continuation of her grand and global civilizing mission [sa grande mission civilisatrice mondiale].' (Hansen \& Jonsson, 2014, p. 238) As for Mr. Europe himself, Belgian foreign minister and socialist Paul-Henri Spaak, defending Europe's colonial course in Africa was an existential cause. Following Egypt's decision to nationalize the Suez Canal in the summer of 1956, for instance, Spaak (1971, p. 126) wrote to the British foreign secretary, Selwyn Lloyd, calling 'for a policy of absolute firmness from the Western Powers' towards Egypt: 'If Nasser's coup is allowed to go unpunished, the prestige of this new dictator will grow vastly, and so will his ambitions and audacity. The entire situation in North, and even in Central Africa, may be affected to our detriment.'

If Western Europe dreaded the prospect of a collapsing colonial order it also tried to convince the colonized to feel the same. One of the strategies pursued was to reiterate the world's growing 'interdependence' in the postwar era-similar to our time's globalization mantra. As part of this, a nation-state system was portrayed as obsolete and anachronistic, even before it had seen the light of the day. 'Dependent peoples' were thus to be persuaded to see national and political independence as a dead-end and instead welcome their incorporation into larger communities, foremost the French Union, or empire, and the EEC. Only such a larger franco-africaine or Eurafrican community could reconcile with the new and commanding stage of 'interdependence' that the world had entered.

In a speech on Algeria before the UN in February 1957, France's foreign minister, socialist Christian Pineau, spoke of 'the so-called right to independence' and of 'the right of peoples to self-determination' as 'a sort of mystic aim of the international organization' that 'would end in multiplying the number of states at a time when, on the contrary, the peoples should be brought together in a common action'. Just like Adenauer, the French foreign minister was apprehensive about the proliferation of states that would result from decolonization. For Pineau and France, therefore, '[t]he most important thing is to promote throughout the world an acceptable standard of living which would enable men of all countries to enjoy true liberty and enable the nations to become something other than states.' Nations, just like the French nation, could be recognized, but they should remain inside the French imperial state and the newly created European or Eurafrican association regime. 'On the day', Pineau asserted, 'when a large common market-in which the overseas territories will be associated-has been created, she [France] would like to promote the formation of a Eurafrican whole. Europe in its entirety, bringing to Africa its capital and its techniques, should enable the immense African continent to become an essential factor in world politics.' (quoted in The New York Times, 1957c). In contrast to this colonial vision, Pineau pointed to the grim alternative: 'What would remain of the prospects thus offered to Algeria if it were to become a foreign land pledged to fanaticism [...]. On the other hand, its participation in Eurafrica would mean for Algeria comfort, riches, in other words, the true conditions of independence.' In conclusion, Pineau reiterated France's contention that the nation-state had had its day, saying '[o]nce again, most nations can no longer keep pace with the world. They must enter into partnership, cooperate with each other, or give themselves up to the worst forms of ideological or economic bondage.' (quoted in The New York Times, 1957c)

Felix Houphouët-Boigny, the first West African cabinet member under Guy Mollet socialist government and future president of Ivory Coast, also argued vehemently in favour of the EEC's association regime, embracing the concepts of interdependence and independence without statehood. Addressing the United Nations in 1957, Boigny criticized the 'notion of absolute independence', adding: 'In this century each nation feels more and more cramped within its boundaries. The nations, even the largest, the most powerful, can no longer enjoy the deceptive luxury of isolation.' (quoted in The New York Times, 1961) Yet again, we see how important it was to insist on a topsy-turvy history, wherein that which had yet to appear (i.e., the nation-state system) was made to look as if 
its time had passed, in order for colonialism-disguised as interdependence, association or partnership-to look modern and equipped for the future.

It is crucial to note that in denying independent statehood to the colonies, Western European states-whether as imperial states or as members of the EEC-were also refusing to become nation-states themselves. Hence, it is not enough to understand decolonization as the folding of European empires and the birth of nominally independent states in the former colonies. Losing their imperial privilege did not only spell the end of imperial statehood; it also entailed the beginning of national statehood in Europe, or at least the horrible prospect thereof. It was a horror, of course, because it would imply a loss of influence and status. Bhambra (2021, p. 2) frames this elegantly by speaking of the British state as 'an imperial state with a national project at its heart'. This compels us to think about nation and empire together, rather than to treat them separately, which is the current norm within the social sciences. Bhambra demonstrates why such a separation is both empirically-historically and theoretically mistaken; and she shows how this fatal mistake enables us to treat empire and colonialism as irrelevant for our studies of the development of the 'national' welfare state.

In contrast to today, many scholars and intellectuals in the postwar period understood very well the inseparability of the imperial state and the national or metropolitan project. And for many of them, like for their peers in government, the prospect of transforming from an imperial system to a system of nation-states caused a lot of debate and trepidation. As so many others at the time, Raymond Aron, one of France's foremost scholars and public intellectuals, worried about what seemed to be a looming multiplication 'of completely independent African states'. 'The ideology of total independence', he agonized, 'triumphs over all arguments, even those of wisdom' (Aron, 1960, p. 186). But when Aron wrote this (in 1958-1959), all was not lost for France: 'the French government has solid reasons for not giving up its sovereignty across the Mediterranean. [...] Without the European minority the Algerian masses would know a still worse fate [...] Algeria is the indispensable southern base of defence of western Europe; it is the access to the oil of the Sahara.' (Aron, 1960, p. 134) As indicated, it was with the help of the EEC that France could keep Algeria and retain its standing as a great power. Going it alone, however, would be very difficult since France lacked the resources to develop Africa on its own. Aron thus saw the EEC as a vehicle through which Western Europe could re-establish the great power status that the members could not attain individually, as nation-states:

[I]t is the will to transmute this community, now under domination [by the superpowers] into an autonomous community of action which is at the root of the European plan. The nations of the old continent are living one and the same historical experience. Will they insist on answering the challenge of their abasement individually? Or will they unite in order to find an answer in common?

(Aron, 1960, p. 163)

For Aron, then, the nation-state was not an option for the 'old continent', unless, that is, 'abasement' was an option. 'If Algeria, in its turn, becomes an independent state', Aron (1960, p. 111) exemplified, 'then France will be reduced to the metropolitan hexagon, dedicated to a quasi-Spanish mediocrity.' As Hoffmann (1963, p. 75) put it a few years later, 'the advocates of little France' had little success, some of which owed to the fact that France was 'a nation which obstinately refuses to behave like Switzerland and which sees in the Swiss form of happiness a solitary confinement rather than a solitary delight.' 'By losing their military positions around the world', Aron (1960, p. 155) wrote, 'Europeans lose, in a way, their autonomy.' As we saw above, Aron wanted the EEC to compensate for that loss by developing 'into an autonomous community of action'. This is absolutely crucial since it clarifies why so many Western scholars and intellectuals at the time dreaded the nation-state. The nation-state spelled weakness, it compromised sovereignty and thus meant a loss of autonomy on the world stage. 
In conclusion, this clarification also points to something fundamental in our present, something that prevents us from gaining that 'more adequate understanding of the shared histories that have configured our present', which Bhambra calls for. Because what should be discernible now is that the alleged and globalization-induced waning of the nation-state' sovereignty and autonomy-which the social sciences have spent decades describing and theorizing-builds on a poor historical understanding. Sovereignty, autonomy of action and many of the other attributes we are taught to associate with the nation-state are rather attributes of empire, of 'great powers', of states with the muscle to colonize others. As shown here, governments of the folding empires in the postwar decades, as well as their intellectuals, all understood this very well. That explains the refusal to give up, the wars, the crimes against humanity, but also the parallel efforts to launch Western European cooperation and integration schemes as means to retain world influence and mitigate the negative effects of the potential degradation to nation-state status, to the 'quasi-Spanish mediocrity'. This was of course also understood by many in the former colonies. In his advocacy of Pan-Africanism and African integration schemes, Kwame Nkrumah, for one, was very clear about the inherent weakness of the newly independent states in West Africa, and, not the least, their vulnerability to continued 'dependence' on and exploitation by their former colonial masters. In 1963, Nkrumah (1963, p. 173) thus issued the following warning:

The greatest danger at present facing Africa is neo-colonialism and its major instrument, balkanization. The latter term is particularly appropriate to describe the breaking up of Africa into small, weak states, since it arose from the actions of the great powers when they divided up the Europe part of the old Turkish Empire and created a number of dependent and competing states in the Balkan peninsula.

Much of the scholarly work today seems unaware of the wide-ranging debates around empire, colonialism and the nation-state that carried on in the postwar period. Brown (2010, p. 22) is thus symptomatic of our current impasse when she mistakes the imperial state for the nation-state, asserting that 'over the past half century, the monopoly of these combined attributes [proceeding from sovereignty] by nation-states has been severely compromised by growing transnational flows'. 'I argue', Brown (2010, p. 23, 24) continues, 'that the key characteristics of sovereignty are migrating from the nation-state [...]. In sum, in a post-Westphalian order, sovereign nation-states no longer exclusively define the field of global political relations'. As I have tried to show here, following Bhambra, it was empires, not nation-states, that played that role.

Charles Maier is similarly symptomatic in his book Leviathan 2.0, where he defines 'the modern state' as prevailing from the 1860 s to the 1970 s. The last decades of the 19 th century, Maier $(2012$, p. 5) explains, 'signaled the last stand for indigenous political autonomy'. After that, there was only one game in town with the victory of 'the most efficient engine of expansion and governance that the world had seen for centuries: the modern nation-state.' Until the 1970s, Maier goes on to argue, the institution of modern states and their 'units of territorial organization prevailed without any real alternative institutions to contest their triumph. Then they entered a period we still live in, one that seems to have imposed some important limitations on their freedom of action' (Maier, 2012, p. 14). As Rupert Emerson wrote in 1963, '[t]he Atlantic Community is in the process of transition from a more or less global domination, exercised by a few of its members, to the establishment of a new style of relationship with its formerly subject or subordinate peoples'. (Emerson, 1963, p. 111) Again, the debate at the time disrupts the alleged stability and continuity of Maier's modern nationstate-just think of decolonization's amazing transformation of the 'territorial organization' of states. As Aron (1960, p. 152) pointed out at the end of the 1950s, '[i]t is in relation to empire that the very meaning of what we call adjustment to the world of today is disputed.' 
In part, our current impasse may stem from the fact that much current scholarship keep to the old beaten track of perceiving of the nation-state, and its alleged sovereignty, as the inventions of Thomas Hobbes. For Brown, Hobbes is one of 'classical theorists of modern sovereignty' and, as such, he serves as a benchmark for her theorization about the nation-state's waning sovereignty in what she terms the 'post-Westphalian order'. For Maier, as stated in the first sentence of the abstract for Leviathan 2.0, 'Thomas Hobbes laid the theoretical groundwork of the nation-state'. There is some truth to this, of course, but given that Hobbes defined the commonwealth, or state, as always the potential possessor of colonies, the Hobbesian state has much less affinity with a nation-state that is commonly assumed; and this simply because a nation state and an imperial state are not the same thing. 'The procreation, or children of a commonwealth', Hobbes (1651 [1996], p. 168) wrote in Leviathan, 'are those we call plantations, or colonies; which are numbers of men sent out from the commonwealth, under a conductor, or governor, to inhabit a foreign country, either formerly void of inhabitants, or made void then by war'. Hobbes, thus, often modelled his commonwealth, or state, on the Roman empire, which makes a lot of sense given that it is here, in the imperial state, that Hobbes' notion of sovereignty applies in full. Hobbesian sovereignty, then, is imperial since it inheres one party's ability to expand its sovereignty at the expense of the sovereignty of others: 'The Athenians, and Romans were free; that is, free commonwealths: not that any particular men had the liberty to resist their own representative; but that their representative had the liberty to resist, or invade other people.' (Hobbes, 1651 [1996], p. 143) 'And as for very little commonwealths', Hobbes (1651 [1996], p. 175) clarifies, that is, those not modelled on the Roman empire, 'there is no human wisdom can uphold them, longer than the jealousy lasteth of their potent neighbours.' Here, then, we may have an apt definition of the quintessential nation-state, the one that, in sharp contrast to the imperial state, lacks both the liberty to resist and to invade. As Carr (1945, pp. 69-70) put it in 1945: 'It is an illusion to suppose that security for the individual or for the nation can be attained through the limited resources of the small or medium-sized nation-states or through the untrammelled and independent action of national governments.' Max Weber thus also mistook the empire for the nation-state when he wrote that "[w]e hesitate to call them "nations", not because of their relative smallness-the Dutch appear to us as a nation-, but because these neutralized states have purposively forsaken power.' (Weber, 1978 [1922], p. 397) While small on the European landmass, the Netherlands had not 'forsaken power'. Why? Because it had a huge empire and thus was not a nation-state.

This should also destabilize the prevailing notion that decolonized states sought to model their new independent states on the European nation-state. The problem with this notion is that there was no such nation-state to copy. The only thing available for them to imitate was an imperial state, and, obviously, they did not try to do that. Neither Guinea nor Algeria pledged to model their states on the French imperial state; neither they nor any other of the decolonized states pledged to colonize their former masters, plunder their resources and subject their peoples to crimes against humanity.

Until the Suez invasion in 1956, the British and French imperial states 'had the liberty' to invade in Africa. In Hobbesian terms, they were 'free commonwealths'. That is also why Suez became such a huge crisis of sovereignty. But it was certainly not a crisis of nation-state sovereignty. When presented like this, I think all would agree that Suez constituted a crisis of imperial sovereignty. Yet, for the past decades, scholars have been claiming, ad nauseam, that 'nation-states no longer exclusively define the field of global political relations', when, in fact, they never did.

As Bhambra shows, British governments needed imperial state sovereignty in order to make their national project viable. Imperial crisis, therefore, also spelled national crisis, and, as I have pointed to here, it spelled a crisis for Western Europe as a whole. Having the scope and reach of state sovereignty reduced to the island or, as in the French case, to the hexagon was never an option. In this sense Bhambra's conception does not dispose of the nation and nationalism; rather, what it does, is to restore these concepts and histories to their proper global contexts, hence paving the way for 'a more adequate understanding of the shared histories that have configured our present'. 
Finally, this should also help us clear up the confusion that permeates some of current ways of critiquing methodological nationalism. In her article Bhambra does not explicitly address methodological nationalism, yet she does it implicitly by asking and then investigating 'how we have come to a national framing of the state and its political community in the present, notwithstanding the wider relationships that have historically defined it' (Bhambra, 2021, p. 2). This, then, is the valid and historically cognizant critique of methodological nationalism. That is to say, we are not methodological nationalists today because we fail to grasp that the allegedly ageold Westphalian nation-state system has been transformed and significantly challenged by global and transnational forces in recent decades. Rather, we are methodological nationalists for mistakenly projecting back the nation-state system into an age when it did not exist. Nonetheless, and as seen in my critique of Brown and Maier above, it is the former perspective that prevails. As put by two of the foremost theorists of methodological nationalism:

Only now that the nation-states have lost some of their power to transnational corporations and supranational organizations can we see, looking backward, what shape modernity has taken during the last 200 years. It was cast in the iron cage of nationalized states that confined and limited our own analytical capacities.

(Wimmer \& Glick Schiller, 2002, p. 302)

For Wimmer and Glick Schiller (2002, p. 302, 304) this failure to spot 'the national framing of modernity', 'in the high days when the nation-state bounded and bundled most social processes', constitutes one of the main forms of what they conceive of as methodological nationalism. But again, this fails to recognize, comprehend and analytically account for the imperial framing of modernity.

Learning about empire and colonialism, as Bhambra urges us to do, is, thus, the best way to un-learn the engrained myths about the nation-state as the great moulder of modern history. By the same token, an improved social science is necessarily also a historically informed social science.

\section{ACKNOWLEDGEMENTS}

The research for this article has been made possible by a grant from Riksbankens Jubileumsfond for the Advancement of the Humanities and Social Sciences.

\section{DATA AVAILABILITY STATEMENT}

Data sharing not applicable to this article as no datasets were generated or analysed during the current study.

\section{ORCID}

Peo Hansen (D) https://orcid.org/0000-0002-0497-473X

\section{ENDNOTES}

${ }^{1}$ Bhambra's reference to The Spirit of 45 is made in her talk (https://www.youtube.com/watch?v=KvzYMtOXBDs) but not in her article.

2 Historical Archives of the European Union, CM 3/NEGO 252, "Groupe Ad hoc territoires d'outre-mer, Projet de préambule," 18 December 1956.

\section{REFERENCES}

Aron, R. (1960). France steadfast and changing: The fourth to the fifth republic. Harvard University Press.

Bayly, C., \& Harper, T. (2007). Forgotten wars: The end of Britain's Asian empire. Allen Lane.

Benoit, E. (1961). Europe at sixes and sevens: The common market, the free trade association and the United States. Columbia University Press. 
Bhambra, G. (2021). Relations of extraction, relations of redistribution: Empire, nation, and the construction of the British Welfare State. British Journal of Sociology.

Brady, S. J. (2010). Eisenhower and Adenauer: Alliance maintenance under pressure, 1953-1960. Lexington Books.

Brown, W. (2010). Walled states, waning sovereignty. Zone Books.

Bullock, A. (1983). Ernest Bevin: Foreign secretary, 1945-1951. Heinemann.

Butler, L. J. (2002). Britain and empire: Adjusting to a post-imperial world. I. B. Tauris.

Carr, E. H. (1945). Nationalism and after. Macmillan.

Cosgrove, C. A. (1969). The common market and its colonial heritage. Journal of Contemporary History, 4, 73-87.

Council of Europe. (1952). The Strasbourg plan. Secretariat-General Council of Europe.

Emerson, R. (1963). The Atlantic community and the emerging countries. In F. O. Wilcox \& H. F. Haviland, Jr. (Eds.), The Atlantic community: Progress and prospects (pp. 110-130). Praeger.

European Council. (2020). The Schuman declaration: where the EU was born. https://www.consilium.europa.eu/en/70schuman-declaration/

European Union. (n.d.), Declaration of 9 May 1950. https:/europa.eu/european-union/about-eu/symbols/europe-day/ schuman-declaration_en

Gallagher, J. (1982). The decline, revival and fall of the British empire. Cambridge University Press.

Granieri, R. J. (2003). The ambivalent alliance: Konrad Adenauer, the CDU/CSU, and the west, 1949-1966. Berghahn Books.

Hansen, P., \& Jonsson, S. (2014). Eurafrica: The untold history of European integration and colonialism. Bloomsbury.

Hick, A. (1991a). The "European movement". In W. Lipgens (Ed.), Documents on the history of European integration (Vol. 4, pp. 319-435). Walter de Gruyter.

Hick, A. (1991b). The European union of federalists (EUF). In W. Lipgens (Ed.), Documents on the history of European integration (Vol. 4, pp. 8-111). Walter de Gruyter.

Himpele, F. (1960). Läuft Afrika der EWG davon? Die Welt, 2 June.

Hobbes, T. (1651 [1996]). Leviathan. Oxford University Press.

Hoffmann, S. (1963). Paradoxes of the French political community in S. Hoffmann et al. (authors), France: Change and Tradition. London: Victor Gollancz.

Kabinettsprotokolle der Bundesregierung. (1957, February 15/2000). Assoziierung der überseeischen Gebiete. In Kabinettssitzung (Vol. 10). R. Oldenbourg Verlag.

Kent, J. (1989). Bevin's imperialism and the idea of Euro-Africa, 1945-49. In M. Dockrill \& J. W. Young (Eds.), British Foreign policy, 1945-56 (pp. 47-76). Macmillan.

Kitzinger, U. (1962). The challenge of the common market. Basil Blackwell.

Kraft, L. (1948). Pan-Africanism: Political, economic, strategic or scientific? International Affairs, 24(April), $218-228$.

Lawrence, M. A. (2007). Forging the "great combination": Britain and the Indochina problem, 1945-1950. In M. A. Lawrence and F. Logevall (Eds.), The first Vietnam war: Colonial conflict and cold war crisis (pp. 105-129). Harvard University Press.

Louis, W. R. (1984). The British empire in the middle east 1945-1951: Arab nationalism, the United States, and postwar imperialism. Oxford University Press.

Maier, C. S. (2012). Leviathan 2.0: Inventing modern statehood. The Belknap Press of Harvard University Press.

Manela, E. (2007). The Wilsonian moment: Self-determination and the international origins of anticolonial nationalism. Oxford University Press.

Mazower, M. (2009). No enchanted palace: The end of empire and the ideological origins of the United Nations. Princeton University Press.

McKay, V. (1963). Africa in world politics. Harper \& Row.

Monnet, J. (1978). Memoirs (R. Mayne, Trans.). Doubleday.

Nkrumah, K. (1962). Address to the nationalists' conference, June 4, 1962. Unidentified Publisher.

Nkrumah, K. (1963). Africa must unite. Panaf Books.

Organisation for European Economic Co-operation. (1951). Investments in overseas territories in Africa, South of the Sahara. Saville, J. (1993). The politics of continuity: British foreign policy and the labour government, 1945-46. Verso.

Schwartz, H.-P. (1997). Konrad Adenauer: A German politician and statesman in a period of war, revolution and reconstruction. Vol. 2: The statesman, 1952-1967. Berghahn Books.

Spaak, P.-H. (1971). The continuing battle: Memoirs of a European 1936-1966. Weidenfeld and Nicolson, English translation, [1969].

The New York Times. (1946). Attlee aides scan East Africa bases, 8 October.

The New York Times. (1947a). Cripps says Colonies hold key to survival, 13 November.

The New York Times. (1947b). Britain holds to near East despite her empire change, 20 October.

The New York Times. (1957a). Germans go to Africa: Bonn mission to study ways to develop resources, 26 March.

The New York Times. (1957b). Europe may get new oil source, 7 October 1957.

The New York Times. (1957c). Excerpts from address during United Nations debate on the algerian question, 5 February. 
The New York Times. (1961). African conciliator: Felix Houphouet-Boigny, 8 August. Uri, P. (1991). Penser pour l'action: Un fondateur de l'Europe. O. Jacob.

Wall, I. M. (1991). The United States and the making of postwar France. Cambridge University Press.

Weber, M. (1978 [1922]). 'Ethnic Groups" and "The Nation"', in Max Weber (author) economy and society. University of California Press.

Wimmer, A., \& Glick Schiller, N.. (2002). Methodological nationalism and beyond: Nation-state building, migration and the social sciences. Global Networks, 2(4), 301-334.

How to cite this article: Hansen, P. (2022). Decolonization and the spectre of the nation-state. The British Journal of Sociology, 73, 35-49. https://doi.org/10.1111/1468-4446.12909 